\title{
Optimum insulation thickness for pipes in district heating systems - review
}

UtkU ILHAN

DOI: 10.30464/jmee.2018.2.3.225

Cite this article as:

Ilhan U. Optimum insulation thickness for pipes in district heating systems - review. Journal of Mechanical and Energy Engineering, Vol. 2(42), No. 3, 2018, pp. 225-232.

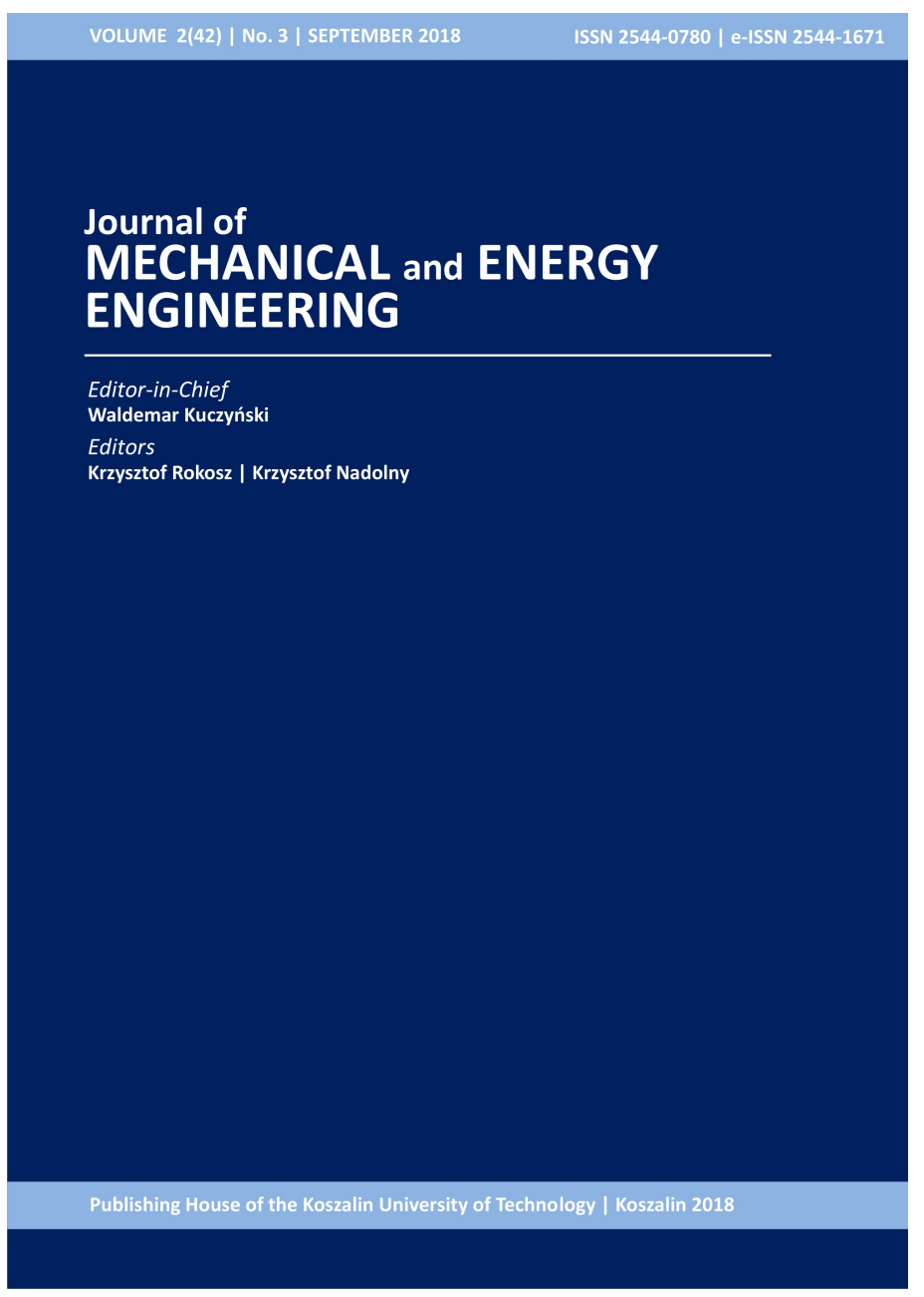

Journal of Mechanical and Energy

Engineering

Website: jmee.tu.koszalin.pl

ISSN (Print): 2544-0780

ISSN (Online): 2544-1671

Volume: $2(42)$

Number: 3

Year: 2018

Pages: 225-232

Article Info:

Received 30 July 2018

Accepted 1 September 2018

\section{Open Access}

This article is distributed under the terms of the Creative Commons Attribution 4.0 (CC BY 4.0) International License (http://creativecommons.org/licenses/by/4.0/), which permits unrestricted use, distribution, and reproduction in any medium, provided you give appropriate credit to the original author(s) and the source, provide a link to the Creative Commons license, and indicate if changes were made. 


\title{
OPTIMUM INSULATION THICKNESS FOR PIPES IN DISTRICT HEATING SYSTEMS - REVIEW
}

\author{
Utku ILHAN $^{1 *}$ \\ ${ }^{1}$ Institute of Sciences, Department of Mechanical Engineering, Balikesir University, Turkey, \\ e-mail: utkuilhan48@gmail.com
}

(Received 30 July 2018, Accepted 1 September 2018)

\begin{abstract}
Energy is an important factor for the social and economic development of communities. The energy performance of insulation systems is an important factor in today's increasing consumption of energy. Insulation in hot water pipelines is done to reduce heat losses caused by building elements. In this study, optimum insulation thickness, annual costs, energy saving and repayment times were evaluated in district heating systems. The evaluations were made for various pipe sizes, various fuel types and various insulation materials considering the heating loads of the regions. In addition, the formulas used for the heat loss and insulation economy are given in the study. As a result, the choice of an optimum insulation thickness in pipelines of district heating systems provides economic and environmental advantages.
\end{abstract}

Keywords: optimum insulation thickness, district heating, energy saving, pipe insulation, heating degree-days, life cycle cost(LCC)

\section{INTRODUCTION}

Energy saving has become the most important part of energy strategies of any country and will continue growing in importance in future; this is because of the fact that energy is a crucial factor for the social and economic development of societies, and energy consumption is rapidly increasing due to increasing population, urbanization, migration to large cities and improvement in the standard of living. Because of limited energy sources, fast energy consumption and environmental pollution from the use of fuels, energy saving has become compulsory. Furthermore, it is not viable to design and implement energy saving plans without considering environmental factors $[1,14,16]$. According to the research done, if the energy consumption in the world continues with the current moment, it is predicted that half of the fossil fuel resources that we have will be consumed in 202. The decline in resources leads to an increase in the unit price of energy resources and also plays a role in increasing the investment / operation cost[2].

In many countries, the energy required for space heating in buildings has the highest share of all, which is about $40 \%$ of total energy consumed in the residential sector and this transport of energy through pipe networks. Especially, heating and cooling demands account for nearly $70 \%$ of building energy requirements Additionally, energy consumption for space heating is nearly two times greater than all other sources of consumption (e.g., water heating, cooking, food cooling and freezing) $[3,13]$.

Effective thermal insulation of piping system plays an important role in the reduction of heat loss and energy consumption for the transmission and distribution of heat in district heating/cooling. The selection of insulation material depends on the thermal conductivity and price: the lower the thermal conductivity and price are, the higher the economical efficiency of insulation material is. The increase of insulation thickness will reduce the energy consumption for heating/cooling, however, the investment for the insulation will increase as well, and then there must be an optimum point where the total investment cost for the insulation and energy consumption can be minimized over the lifetime. Therefore, the selection of proper insulation material, as well as the determination of optimum insulation thickness is very critical for the analyses $[4,12]$.

The sole purpose of a district heating system is to supply adequate heat to its customers. The consumer uses heat to maintain indoor temperature at a reasonably constant level and counter for the 
building's heat loss to the surroundings. Most district heating systems use conventional fuels (oil, natural gas or coal) as the heat source. In some areas, geothermal heat is used as the district heating source. The heat distribution in district heating systems is carried out by the use of either hot water or steam through a closed loop network, where hot water or steam is piped to each consumer in the supply network, cooled down by the heat consumer, piped back to the heat centre and re-heated. To reduce the heat loss efficiently in such a heating system, the proper insulation should be selected by accounting for the purpose, environment, ease of handling, and installation cost. Industrial and chemical processing plants in particular contain intricate and costly piping configurations. Piping systems are also employed in many other situations including water supply, fire protection, and district heating/cooling applications. For example, un-insulated steam distribution and condensate return lines are a constant source of wasted energy $[1,16]$. The thickness of insulation material is preferred considering the average ambient temperature of the zone, the thermal conductivity of the insulation material and its cost. Increasing the thickness of the insulation material will not only reduce air pollution but will also increase energy savings. However, an insulation thickness that provides zero heat loss is neither practically nor economically viable. An equilibrium point is obtained, which is determined between the cost of the insulation material and the savings. This equilibrium point also indicates the optimum insulation thickness $[5,17,18]$.

\section{METHODOLOGY USED FOR DETERMINING THE OPTIMUM INSULATION THICKNESS}

As the thickness of the insulation material increases, the energy consumption for heating will decrease. But in this case the cost of insulation will increase and this will increase the total investment cost. For this reason, insulation has an optimum insulation thickness value, in which the total investment cost is minimized. In contrast to flat surfaces, the variation in the amount of insulation used on a pipe versus the insulation thickness is not linear but rather, the increase is parabolic (Figure 1 ) [6].

Heat transportation in district heating/cooling systems and in industrial and chemical processing plants is performed by the use of hot/cold fluid through a closed loop network. The basic element of such a system is the pipe, which enables the transport of energy; however, pipes also represent a significant source of heat losses. Heat gain, heat loss and temperature change in pipes are substantially influenced by the insulation material, the surrounding environment (i.e., ambient air for above-ground pipe or soil for underground pipe), and the pipe structure $[5,7,16]$.

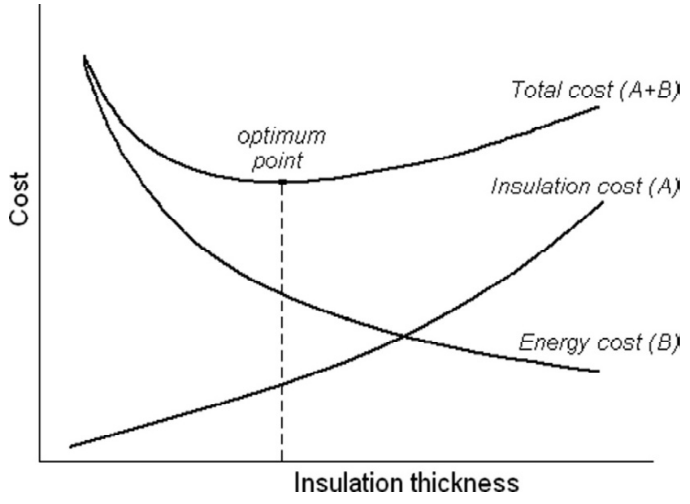

Fig. 1. Optimum insulation thickness [6]

The hot water piping system is shown in Figure 2 for unit length. It is a long straight conduit segment, installed in the environment with the temperature and pressure, which are also identical to those of the dead state. The assumptions are a constant environmental temperature and constant thermodynamic properties at an appropriate mean temperature. In addition, hot water for a district heating system is pumped through the pipe with a constant velocity under steady-state steady-flow control volume conditions $[1,8,9,15]$.

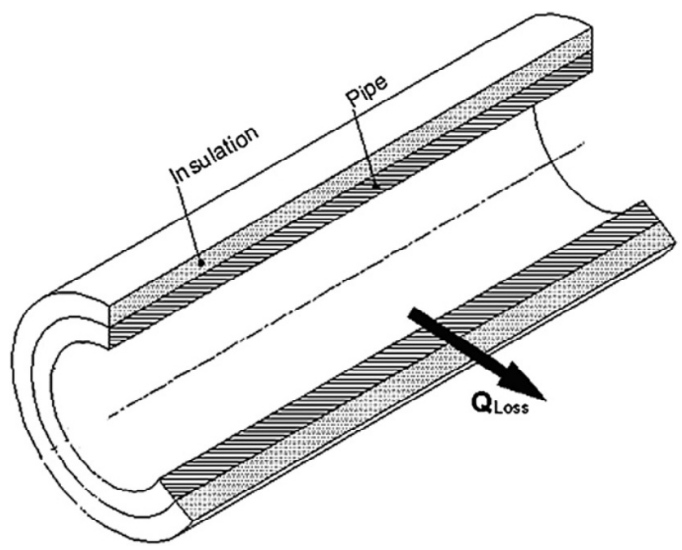

Fig. 2. Heating systems pipe cross section [1]

\subsection{Heat losses for the piping system}

In a district heating pipeline, heat losses caused byfrom the pipe can generally be calculated by

$$
Q_{p}=U A\left(T_{a d}-T_{o}\right)=U A \Delta T,
$$

where $\mathrm{A}$ is the total surface area of the pipe, $T_{o}$ is the temperature of outside air, $T_{a d}$ is the average design temperature of the inside fluid, and $U$ is the total heat transfer coefficient.

The total internal resistance of any pipeline, $R p$, is equal to the summation of the surface resistances of convective heat transfer over the inside and outside surfaces of the pipe, and the total internal resistance of all the layers of the pipeline is given as: 


$$
R_{p}=\frac{1}{h_{i} A_{i}}+\frac{\ln \left(\frac{r_{1}}{r_{0}}\right)}{2 \pi L k_{1}}+\frac{\ln \left(\frac{r_{2}}{r_{1}}\right)}{2 \pi L k_{2}}+\cdots \frac{\ln \left(\frac{r_{n}}{r_{n-1}}\right)}{2 \pi L k_{n}}+\frac{1}{h_{0} A_{0}},
$$

where $k_{1}, k_{2}$ etc. are thermal conductivities of the layers of the pipeline, and $r_{1}, r_{2}$, etc. are their radiuses. And, the inside surface area of the pipe is $A_{\mathrm{i}}=2 \pi L r_{0}$ while the outside surface area of the last layer of the pipeline is $A_{0}=2 \pi L r_{\mathrm{n}}$

In this study, the total internal resistance of an uninsulated pipeline used is

$$
R_{p, u n-i n s}=\frac{1}{h_{i} A_{i}}+\frac{\ln \left(\frac{r_{1}}{r_{0}}\right)}{2 \pi L k_{1}}+\frac{1}{h_{0} A_{0}}
$$

and the total internal resistance of an insulated pipeline is

$$
R_{p, \text { ins }}=\frac{1}{h_{i} A_{i}}+\frac{\ln \left(\frac{r_{1}}{r_{0}}\right)}{2 \pi L k_{1}}+\frac{\ln \left(\frac{r_{2}}{r_{1}}\right)}{2 \pi L k_{\text {ins }}}+\frac{1}{h_{0} A_{0}},
$$

where $k_{\text {ins }}$ is the heat transfer coefficient of the insulation material and $A_{0}=2 \pi L r_{\mathrm{n}}$ is the outside surface area of the last layer of the pipeline. And $h_{i}$ and $h_{o}$ are the convection heat transfer coefficients for the inside and outside surfaces of the pipeline, respectively.

The difference between the overall heat transfer coefficients of un-insulated and insulated pipelines can be written as:

$$
\Delta U=U_{\text {un-ins }}-U_{\text {ins }}=\frac{1}{R_{u n-i n s}}-\frac{1}{R_{p, i n s}} .
$$

An analysis of the annual energy consumption and cost usually accompanies design heat load calculations and plays an important role in the selection of a heating system. There are various methods for the calculation of annual energy consumption. The simplest and most intuitive way of estimating the annual energy consumption of a building is the degree-days method, which is a steady-state approach. The number of annual heating degree-days (HDD) using hourly data is determined from:

$$
H D D=(1 \text { year }) \sum_{1}^{365}\left(T_{b}-T_{s a}\right)^{*},
$$

where $T_{b}$ is the base temperature and $T_{\mathrm{sa}}$ is the solarair temperature for each hour. The * sign above the parenthesis indicates that only positive values are to be counted, and the temperature difference is to be taken to be zero when $T_{b}<. T_{s a}$. The base temperature is the outdoor temperature below which heating is needed. The annual heat loss from pipeline can be determined using the heating degree-days as given by:

$$
Q_{A}=86400 \mathrm{HDD} U \text {. }
$$

The annual energy requirement for heating losses in the pipeline can be calculated by dividing annual heat loss to the efficiency of the heating system $\left(\eta_{s}\right)$ :

$$
E_{w}=\frac{86400 H D D U}{\eta_{s}},
$$

and the annual fuel consumption for heating losses is:

$$
m_{f}=\frac{86400 H D D U}{H_{u} \eta_{S}}
$$

where $H_{u}$ is a lower heating value of the fuel depending on the fuel type. The annual total energy cost for heating transmission is given by:

$$
C_{f}=\frac{86400 H D D U C_{F}}{H_{u} \eta_{s}},
$$

where $C_{F}$ is the fuel cost depending on the fuel type. The total cost of insulation depending on the cost of the insulation material per unit volume can be calculated as:

$$
C_{\text {ins }}=C_{1} V
$$

where $C_{1}$ is the cost of the insulation material and $V=\frac{\pi}{4}\left(r_{2}{ }^{2}-r_{1}{ }^{2}\right) L$ is the volume of the material used in insulation.

To calculate insulation economy, it is necessary to identify the ratio of life cycle energy $\left(P_{1}\right)$ and the ratio of life cycle expenditures incurred to the initial investment $\left(P_{2}\right)$ because of the additional capital investment. $P_{1}$ has a relation with an increase rate (or inflation rate) (d), a discount rate (interest rate) (i), and lifetime $(\mathrm{N})$ as expressed by:

$$
P_{1}=\frac{1}{(d-i)}\left[1-\left(\frac{1+i}{1+d}\right)^{N}\right] \text { if } i \neq d
$$

If the increase rate (d) is equal to the discount rate (i), $P_{1}$ is calculated from:

$$
P_{1}=\frac{N}{1+i} \text { if } i=d .
$$

$P_{2}$ is the ratio of the life cycle expenditures incurred because of the additional capital investment to the initial investment. $P_{2}$ is defined by:

$$
P_{2}=1+P_{1} M_{s}-\frac{R_{v}}{(1+d)^{N}},
$$

where $M_{S}$ is the ratio of the annual maintenance and operation cost to the original first cost, $R_{v}$ is the ratio of the resale value to the first cost. $P_{2}$ can be taken as 1 if the maintenance and operation cost is zero.

The total cost of heat transmission in the insulated pipeline can be calculated as:

$$
C_{t}=P_{1} C_{f}+P_{2} C_{\text {ins }} .
$$

The net energy cost savings over the lifetime for heat transmission from using the insulation material can be formulated with $P_{1}-P_{2}$ method as:

$$
S=\frac{86400 P_{1} H D D U C_{F}}{H_{u} \eta_{s}}-P_{2} C_{i n s} V .
$$

\section{EXAMINATION AND EVALUATION OF STUDIES}

Keçebas [5] explored the optimum insulation thickness, energy saving for a span of 20 years and 
repayment time using the LCC method for Afyonkarahisar province. Optimum insulation thickness was determined for different pipe diameters and 4 different fuels. XPS was used as the insulation material (Density: $30 \mathrm{~kg} / \mathrm{m} 3$, thermal conductivity coefficient: 0,032 W/ m, unit cost: $157 \mathrm{TL} / \mathrm{m}^{3}$ ). In the study, the optimum insulation thickness for different fuels and pipe nominal sizes in Afyonkarahisar province ranged from 0.122 to 0.318 $\mathrm{m}$, energy savings ranged from 72.88 to 639.24 TL / $\mathrm{m}$ and the return period ranged from 0.73 to 1.33 years. In Afyonkarahisar province, the lowest optimum insulation thickness for all the pipe diameters in geothermal energy is the highest fuel-oil fuel. In relation to the small diameter pipes in operation, more energy can be saved by insulation made in large diameter pipes [5].

Optimum insulation for nominal pipe sizes when various fuel types are used is found in Figure 3.

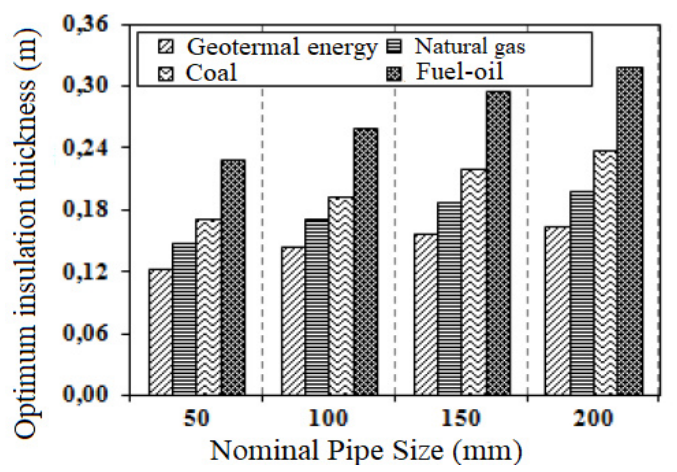

Fig. 3. Variation of optimum insulation thickness with nominal pipe size for different fuels [5]

Y.Çaşoğul and A.Keçebaş [1] have investigated the energy, economic and environmental effects of the optimum insulation thickness in district heating systems for the city of Afyonkarahisar/Turkey. In the study, the energy saving over a lifetime of 10 years, the payback period and emissions of $\mathrm{CO}_{2}, \mathrm{CO}$ and $\mathrm{SO}_{2}$ are calculated for nominal pipe sizes and fuel types. Rock wool was used as the insulation material [1].

Fig. 4 shows the effect of insulation thickness on energy savings for different fuel types. The highest values of energy savings are reached for LPG fuel, whereas its lowest values are obtained for geothermal energy [1].

In Fig. 5, the effect of degree-days on insulation thickness for various nominal pipe sizes is shown. According to the graph, insulation thickness increases with degree days and nominal pipe sizes. At a given number of degree-days, pipelines having higher thermal resistance require less insulation. The results show that the optimum insulation thicknesses vary between 0.074 and $0.223 \mathrm{~m}$ depending on the degreedays.

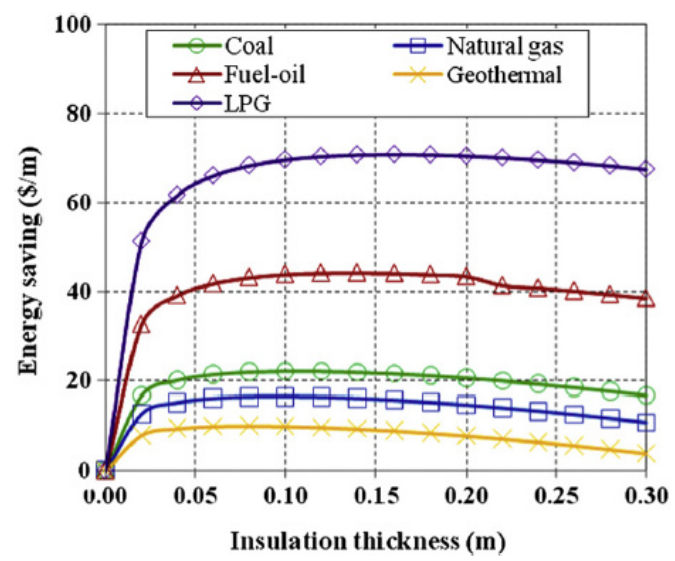

Fig. 4. Effect of insulation thickness on energy savings for different fuel types in a nominal pipe size of $50 \mathrm{~mm}$ [1].

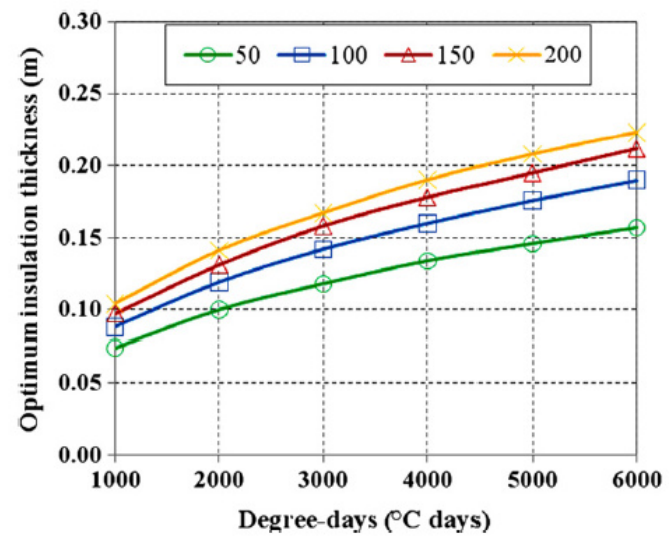

Fig. 5. The optimum insulation thickness versus degreedays for various nominal pipe sizes by using coal fuel [1]

Table 1 shows the optimum insulation thickness, energy saving and repayment time for each nominal pipe size and fuel type. It appears that the optimum insulation thicknesses vary between 0.085 and 0.259 $\mathrm{m}$, the energy savings vary between 10.041 and $231.299 \$ / \mathrm{m}$, and the payback periods vary between 0.442 and 0.804 years depending on the type of fuel and nominal pipe sizes. It appears that the highest value of the energy savings of all nominal pipe sizes is reached by using LPG as an energy source, while the lowest energy saving is obtained by using geothermal energy. And, the highest payback period is from geothermal, followed by natural gas, coal, fuel-oil and LPG.

M. Ertürk (2016) [10] has made a study related to the optimum insulation thickness in steel pipes according to different pipe sizes, different insulation materials and different fuel types. The study was carried out for over 10-year life time using the life cycle cost (LCC) method for Afyonkarahisar province. The pipe sizes used in this study are $50 \mathrm{~mm}, 100 \mathrm{~mm}$, $200 \mathrm{~mm}, 400 \mathrm{~mm}, 600 \mathrm{~mm}, 800 \mathrm{~mm}, 1000 \mathrm{~mm}$. 
Tab. 1. Optimum insulation thickness, energy savings and payback periods with various fuels and pipe sizes for rock wool insulation material [1]

\begin{tabular}{|c|c|c|c|c|c|}
\hline & \multirow[t]{2}{*}{ Fuel types } & \multicolumn{4}{|c|}{ Nominal pipe sizes } \\
\hline & & 50 & 100 & 150 & 200 \\
\hline \multirow{5}{*}{$\begin{array}{l}\text { Optimum } \\
\text { insulation } \\
\text { thickness } \\
\text { (m) }\end{array}$} & Coal & 0.115 & 0.138 & 0.153 & 0.163 \\
\hline & Natural gas & 0.103 & 0.124 & 0.136 & 0.146 \\
\hline & Fuel-oil & 0.152 & 0.183 & 0.202 & 0.216 \\
\hline & Geothermal & 0.085 & 0.102 & 0.112 & 0.118 \\
\hline & LPG & 0.184 & 0.219 & 0.244 & 0.259 \\
\hline \multirow{5}{*}{$\begin{array}{l}\text { Energy } \\
\text { saving } \\
(\$ / \mathrm{m})\end{array}$} & Coal & 22.039 & 40.067 & 57.183 & 72.26 \\
\hline & Natural gas & 16.43 & 29.881 & 42.651 & 53.88 \\
\hline & Fuel-oil & 44.139 & 80.134 & 114.36 & 144.6 \\
\hline & Geothermal & 10.041 & 18.268 & 26.063 & 32.91 \\
\hline & LPG & 70.705 & 128.25 & 182.93 & 231.3 \\
\hline \multirow{5}{*}{$\begin{array}{l}\text { Payback } \\
\text { period } \\
\text { (years) }\end{array}$} & Coal & 0.611 & 0.582 & 0.576 & 0.578 \\
\hline & Natural gas & 0.679 & 0.657 & 0.645 & 0.657 \\
\hline & Fuel-oil & 0.494 & 0.461 & 0.444 & 0.442 \\
\hline & Geothermal & 0.804 & 0.791 & 0.789 & 0.792 \\
\hline & LPG & 0.433 & 0.389 & 0.376 & 0.367 \\
\hline
\end{tabular}

The fuels used include coal, natural gas and fuel oil. The insulation materials are rock wool, EPS and XPS. In the study, the optimum insulation thickness varies from $5.18 \mathrm{~cm}$ to $15.80 \mathrm{~cm}$. As a result of used pipe geometry, the insulation cost curve is not linear for small diameter pipes, while for large diameter pipes this linearity increases. This is caused by the fact that in large diameter pipes, the proportion of the exposed pipe outside surface area compared to the flow capacity is reduced. Large diameter pipes provide greater energy savings compared to small diameter pipes. The most energy saving fuel type related to fuel costs is found as fuel-oil, which is followed by coal and natural gas. Moreover, the greatest saving among the insulation materials is EPS [10].

Figures 6 and 7 show optimum insulation thickness graphs for different fuel types and various nominal pipe sizes, and Figure 8 shows the optimum insulation thickness for 3 different insulation materials and various nominal pipe sizes. According to the graphs, the increase in optimum insulation thickness depends on the increase in the nominal pipe size. However, in large diameter pipes, the optimum insulation thickness is close to the same values. This means that a fixed optimum insulation thickness can be used for large diameter pipes. This situation is related to the reduction in the pipe outer surface area against flow capacity. This relationship reduces heat losses in the fluid flowing along the pipeline [10].

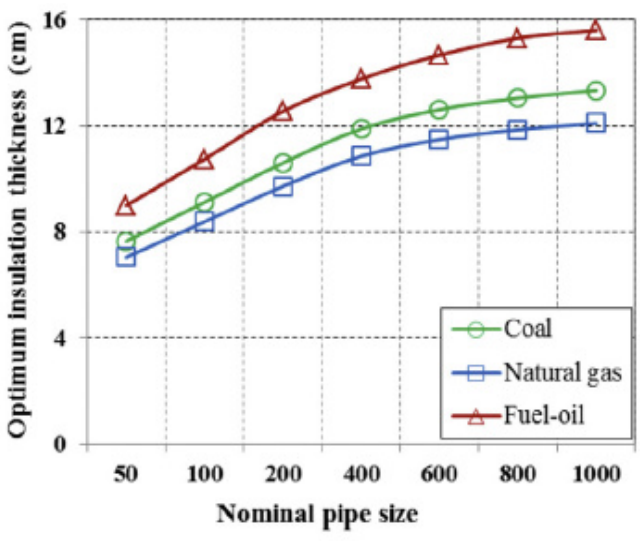

Fig. 6. Optimum insulation thickness relying on different nominal pipe sizes and fuels for EPS insulation material [10]

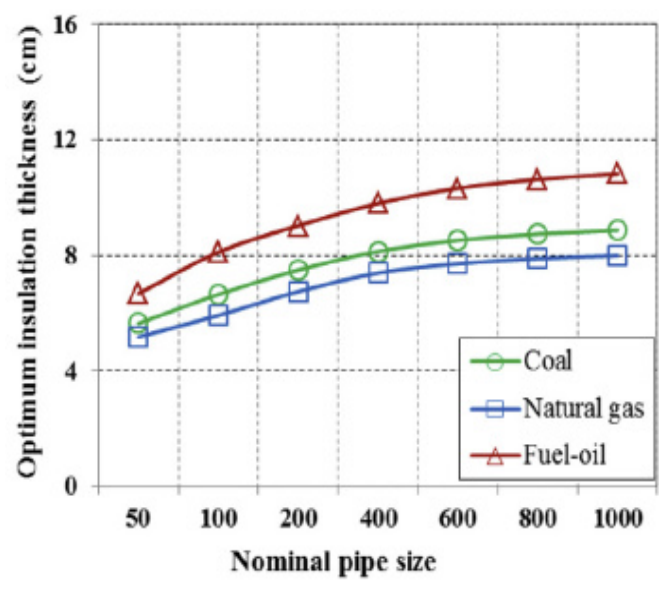

Fig. 7. Optimum insulation thickness relying on different nominal pipe sizes and fuels for XPS insulation material [10]

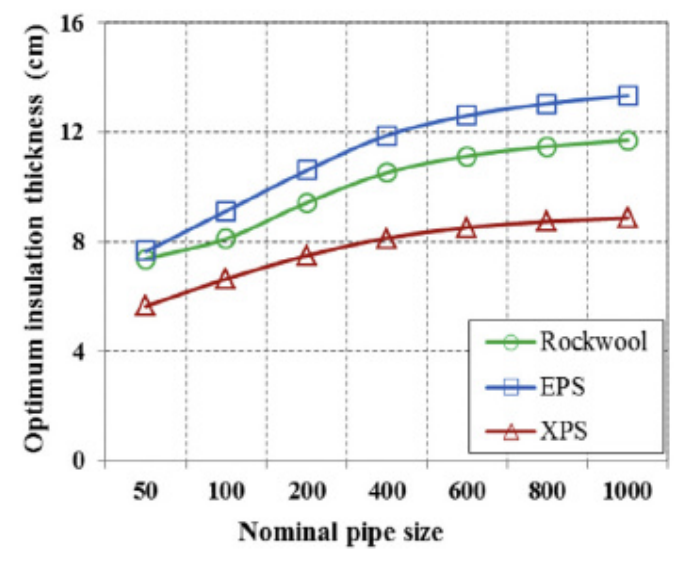

Fig. 8. Optimum insulation thickness relying on various nominal pipe sizes and insulation materials for coal [10]

M. Kayfeci (2013)[8] has determined the energy savings and optimum insulation thickness of the heating piping systems for different insulation 
materials. The study was carried out for over 10-year life time using the life cycle cost (LCC) method for Isparta city in Turkey. The pipe sizes used in this study are $50 \mathrm{~mm}, 100 \mathrm{~mm}, 150 \mathrm{~mm}, 200 \mathrm{~mm}, 250$ $\mathrm{mm}$. The fuel used is natural gas and the insulation materials used are rock wool, XPS, EPS, fiberglass and foam board. As a result of the calculations, the optimum insulation thickness was found to vary between 0.048 and $0.134 \mathrm{~m}$, the energy-saving was found to vary between 10.84 and $49.78 \$ / \mathrm{m}$; and the payback period was found to vary between 0.74 and 1.29 years. According to these results, EPS insulation material with a nominal diameter of $250 \mathrm{~mm}$ provides the highest energy savings, while the lowest value was found to be in fiberglass insulation material with 50 $\mathrm{mm}[8]$.

For $100 \mathrm{~mm}$ nominal pipe size, the changes in total lifetime energy savings of different insulation materials, depending on insulation thickness, are shown comparatively in Fig. 9, where the energy saving for fiberglass insulation is $25.96 \$ / \mathrm{m}$, while the energy saving for EPS insulation is $28.45 \$ / \mathrm{m}$. Energy savings depend on the insulation thickness. An increase in the insulation thickness that exceeds investment cost provides increases in energy savings from fuel costs. With an increase in the insulation thickness, the optimum insulation thickness was gained from the point at which the saving begins to decrease [8].

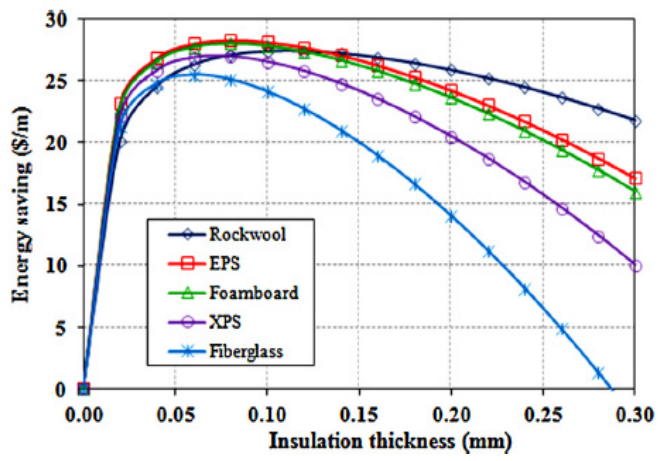

Fig. 9. Effect of insulation thickness on energy savings for various insulation materials in a nominal pipe size of $100 \mathrm{~mm}[8]$

Figure 10 shows the optimum insulation thickness for 5 different insulation materials and various nominal pipe diameter. According the figure, with an increase in the nominal pipe thickness, the optimum insulation thickness increases as well. The maximum insulation thickness was obtained from $250 \mathrm{~mm}$, when rock wool was used as an insulation material and the minimum insulation thickness was obtained from 50 $\mathrm{mm}$, when fiberglass was used as an insulation material. This is because the heat transfer coefficient of the insulation material that consists of rock wool was high.

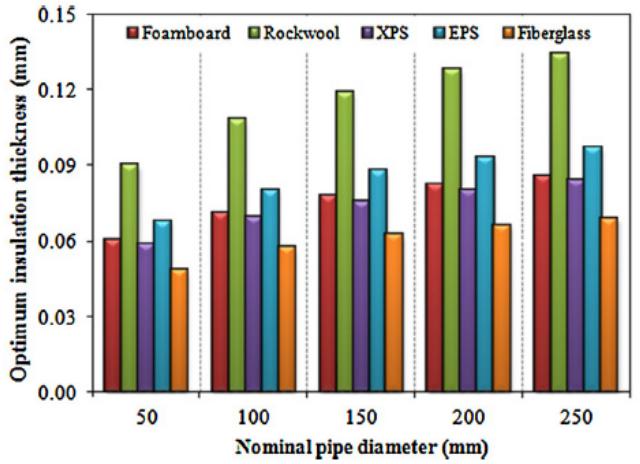

Fig. 10. Optimum insulation thickness depending on different nominal pipe diameter and insulation materials for natural gas fuel [8]

M. Kayfeci, İ. Yabanova and A. Keçebaş (2013)[11] used the artificial neural network method to find the optimum insulation thickness, the total cost, cost savings and the repayment period considering an LCC analysis. The ANN detects the statistical interrelationship between a set of input and output parameters. The fuel used is natural gas and the insulation materials used are rock wool, XPS, EPS and fiberglass. According to the results, the optimum insulation thickness obtains a high value as the climatic conditions get harder and the fuel cost increases [8].

Figure 11 shows the relation between HDD and OIT. According to the specification, OIT increases as the HDD increases. It occurs when a high OIT value rockwool insulation material is used.

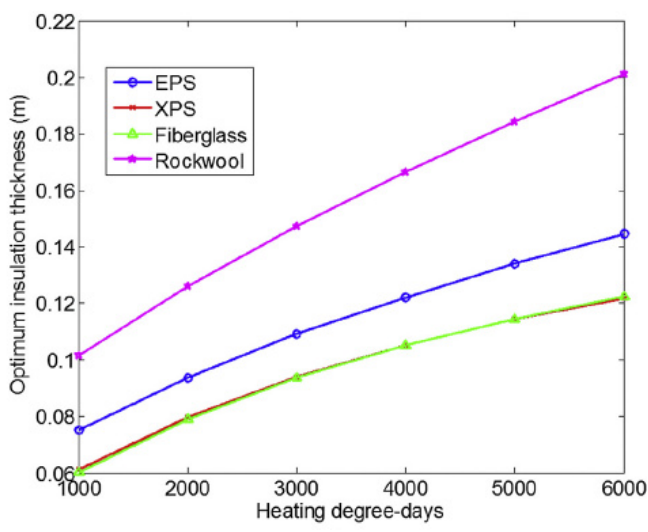

Fig. 11. The optimum insulation thickness versus heating degree-days for $100 \mathrm{~mm}$ nominal pipe size by using natural gas [11]

Figure 12 shows that the optimum insulation thicknesses of the pipes in low heating degree-days (HDD) are close to each other. In addition, the optimum thicknesses of larger pipe sizes in the same HDD are close to each other. Thus, the same insulation thickness can be used for larger nominal pipe sizes. 


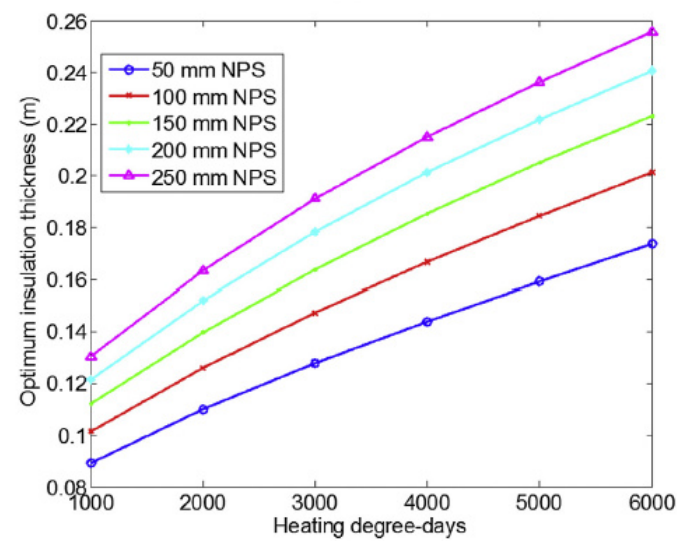

Fig. 12. The effect on optimum insulation thickness of heating degree-days for rockwool insulation material [11]

\section{CONCLUSIONS}

When modeling the thermal performance of district heating pipelines, it is crucial to find techniques to design and analyze problems such as energy savings, energy demands, environmental comfort and control of the piping system. The insulation material installed at its optimum insulation thickness in the district heating pipelines will not only reduce the heat loss from the district pipeline but also offers economical and environmental advantages. In this study, the optimum insulation thickness for the pipelines in the district heating systems was examined with results from various articles. The variation of the optimum insulation thickness with different insulation materials, different pipe sizes and different heating degree days was investigated.

\section{Nomenclature}

\section{Symbols}

$Q_{p} \quad$ heat losses caused by pipe, W

$Q_{\text {save }} \quad$ pipe heat load between un-insulated and insulated piping systems, W

$Q_{\text {A }} \quad$ annual heat loss, W

$R_{\mathrm{p}} \quad$ total internal resistance of piping system, K/W

$R_{\mathrm{p} \text {,un-ins }}$ internal resistance of un-insulated pipe, $\mathrm{K} / \mathrm{W}$

$R_{\mathrm{p} \text {,ins }} \quad$ internal resistance of insulated pipe, $\mathrm{K} / \mathrm{W}$

$U \quad$ overall heat transfer coefficient, $\mathrm{W} / \mathrm{m} \mathrm{K}$

Uins overall heat transfer coefficient of insulated pipe, $\mathrm{W} / \mathrm{m}^{2} \mathrm{~K}$

Uun-ins overall heat transfer coefficient of un-insulated pipe, $\mathrm{W} / \mathrm{m}^{2} \mathrm{~K}$

$\Delta U$ difference between overall heat transfer coefficients of un-insulated and insulated pipes

$T_{\mathrm{ad}} \quad$ average design temperature of inside fluid, $\mathrm{K}$

$T_{\mathrm{o}} \quad$ design temperature of outside air, $\mathrm{K}$

$T_{\mathrm{ms}} \quad$ the mean outside surface temperature of piping system, K

$T_{\mathrm{b}} \quad$ base temperature, $\mathrm{K}$

$T_{\text {sa }} \quad$ solar-air temperature for each hour, K $h_{\mathrm{i}} \quad$ convection heat transfer coefficient for the inside of the pipe, $\mathrm{W} / \mathrm{m}^{2} \mathrm{~K}$

$h_{\mathrm{o}} \quad$ convection heat transfer coefficient for the outside of the pipe, $\mathrm{W} / \mathrm{m}^{2} \mathrm{~K}$

$k_{\mathrm{i}} \quad$ heat transfer coefficient of fluid in the inside of the pipe, $\mathrm{W} / \mathrm{m} \mathrm{K}$

$k_{\text {ins }} \quad$ thermal conductivity of insulation material, $\mathrm{W} / \mathrm{mK}$

$\eta_{s} \quad$ efficiency of the heating system

$H_{\mathrm{u}} \quad$ lower heating value of the fuel, $\mathrm{J} / \mathrm{kg}, \mathrm{J} / \mathrm{m}^{3}, \mathrm{~J} / \mathrm{kW} \mathrm{h}$

$C_{I} \quad$ cost of insulation material per unit volume, $\$ / \mathrm{m}^{3}$

$C_{F} \quad$ fuel cost, $\$ / \mathrm{kg}, \$ / \mathrm{m}^{3}, \$ / \mathrm{kW} \mathrm{h}$

$C_{\mathrm{f}} \quad$ annual energy cost, $\$$

$C_{\text {ins }} \quad$ total insulation cost, $\$$

$C_{t} \quad$ total cost of heating, $\$$

$V$ the volume of insulation material, $\mathrm{m}^{3}$

$E_{\mathrm{W}}$ total annual energy requirement for heating annual fuel consumption for heating

life cycle energy

life cycle expenditures

increase rate, $\%$

discount rate, $\%$

lifetime, years

difference between inside and outside design

temperature, $\mathrm{K}$

length of pipe, $\mathrm{m}$

total surface area of pipe, $\mathrm{m}^{2}$

inside surface area of pipe, $\mathrm{m}^{2}$

outside surface area of last layer of pipe, $\mathrm{m}^{2}$

energy savings, \$

payback period, years

\section{Acronyms}

ANN artificial neural network

EPS expanded polystyrene

HDD heating degree-days

LCC life cycle cost

OIT optimum insulation thickness

XPS extrude polystyrene

\section{References}

1. Başoğul, Y., Keçebaş, A. (2011). Economic and environmental impacts of insulation in district heating pipelines. Energy, Vol. 36, Issue 10, pp. 6156-6164.

2. Oymak, M. (2007). Determination of economic insulation thicknesses in thermal system design by exergy economic method, Publishing House of Trakya University, Edirne. (in Turkish)

3. Daşdemir, A., Ertürk, M., Keçebaş, A., Demircan, C. (2017). Effects of air gap on insulation thickness and life cycle costs for different pipe diameters in pipeline. Energy, Vol. 122, pp. 492-504.

4. Keçebaş, A. (2012). Determination of insulation thickness by means of exergy analysis in pipe insulation. Energy conversion and management, Vol. 58, pp. 76-83.

5. Keçebaş, A. (2012). Determination of optimum insulation thickness for energy saving through pipe insulation in district heating systems. Electronic Journal of Machine Technologies, Vol. 9, No. 1, pp. 1-14.

6. Kaynakli, O. (2014). Economic thermal insulation thickness for pipes and ducts: a review study. Renewable and Sustainable Energy Reviews, Vol. 30, pp.184-194.

7. Başoğul, Y., Demircan, C., Keçebaş, A. (2016). Determination of optimum insulation thickness for environmental impact reduction of pipe 
insulation. Applied Thermal Engineering, Vol. 101, pp. 121-130.

8. Keçebaş, A., Alkan, M. A., Bayhan, M. (2011). Thermoeconomic analysis of pipe insulation for district heating piping systems. Applied Thermal Engineering, Vol. 31, Issues 17-18, pp. 3929-3937.

9. Kayfeci, M. (2014). Determination of energy saving and optimum insulation thicknesses of the heating piping systems for different insulation materials. Energy and Buildings, Vol. 69, pp. 278-284.

10. Ertürk, M. (2016). Optimum insulation thicknesses of pipes with respect to different insulation materials, fuels and climate zones in Turkey. Energy, Vol. 113, pp. 9911003.

11. Kayfeci, M., Yabanova, İ., Keçebaş, A. (2014). The use of artificial neural network to evaluate insulation thickness and life cycle costs: Pipe insulation application. Applied Thermal Engineering, Vol. 63, Issue 1, pp. 370-378.

12. Yavuz, C., Atik, K. (2011).Thermo-economic optimization of the pipe diameters of hot water heating systems. Electronic Journal of Machine Technologies, Vol. 8, No. 4, pp. 53-64.

13. Keçebaş, A. (2015). Determination of optimum insulation thickness in pipe for exergetic life cycle assessment. Energy Conversion and Management, Vol. 105 , pp. 826-835.

14. Sahin, A. Z., Kalyon, M. (2005). Maintaining uniform surface temperature along pipes by insulation. Energy, Vol. 30(5), pp. 637-647.

15. Öztürk, İ. T., Karabay, H., Bilgen, E. (2006). Thermoeconomic optimization of hot water piping systems: A comparison study. Energy, Vol. 31, pp. 2094-2107.

16. Kürekci, N. A. (2013). Optimum insulation thickness for pipes in four heating degree days region of Turkey. In: 11th. International Conference of Plant Engineering, İmir, Turkey, 17-20 April.

17. Keçebas, A. (2013). Variation of insulation thickness and exergetic cost saving with outdoor temperature in pipe insulation. Environmental Progress \& Sustainable Energy, Vol. 32, No. 3, pp. 784-789.

18. Özdemir, M., Parmaksızoğlu, C. İ. (2006). Economic insulation thickness in mechanical installation. Journal of plant engineering, No. 91, pp. 39-41.

\section{Biographical note}

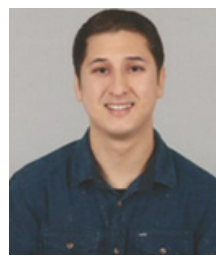

Utku Ilhan graduated from the Balıkesir University, the Department of Mechanical Engineering in Turkey. Currently studying for master degree at the same university. Erasmus + student at the Faculty of Mechanical Engineering at Koszalin University of Technology. İnsulation for pipes, heating systems are found in his field of interest. 